\title{
DETERMINATION OF C-TERMINAL SEQUENCES BY DIGESTION WITH SERINE CARBOXYPEPTIDASES: THE INFLUENCE OF ENZYME SPECIFICITY
}

by

\author{
KLAUS BREDDAM \\ and \\ MARTIN OTTESEN
}

Department of Chemistry, Carlsberg laboratory,
Gamle Carlsberg Vej 10, DK-2500 Copenhagen Valby

Keywords: Carboxypeptidase, serine carboxypeptidase, sequence determination, trypsin, HPLC

\begin{abstract}
It is demonstrated that $\mathrm{C}$-terminal sequence determinations of a number of proteins and peptides by digestion with serine carboxypeptidases often require use of different reaction conditions and/or use of carboxypeptidases with different specificities. The commonly utilized carboxypeptidase $Y$ from yeast with preference for hydrophobic amino acid residues is conveniently supplemented by carboxypeptidase II from malt which includes Lys and Arg in its specificity range. This renders it particularly suitable for C-terminal digestion of tryptic peptides. In some cases a phenylmercuric chloride modified derivative of carboxypeptidase $\mathrm{Y}$ which has a decreased preference for hydrophobic amino acid residues can be used with advantage.
\end{abstract}

\section{INTRODUCTION}

The ability of carboxypeptidases to sequentially release amino acids from the C-terminus of a peptide chain has frequently been used in the elucidation of primary structures of peptides and proteins. Originally, the mammalian metallo carboxypeptidases $A$ and $B$ were used, the former being specific for the release of amino acids with uncharged side-chains except proline and the latter for the release of those with a positive charge, i.e. lysine and arginine (1). In recent years the use of serine carboxypeptidases $(11,13,16)$ and in particular carboxypeptidase Y (CPD-Y) from yeast has become wide-spread.

Abbreviations: $\mathrm{Bz}=\mathrm{N}$-benzoyl; $\mathrm{CPD}-\mathrm{Y}=$ carboxypeptidase $\mathrm{Y}$; $\mathrm{CPD}-\mathrm{M}-\mathrm{II}=$ malt carboxypeptidase $\mathrm{II} ; \mathrm{Cys}\left(\mathrm{SO}_{3}{ }^{\circ}\right)$ = cysteic acid; $\mathrm{Cys}(\mathrm{PE})=$ pyridylethylcysteine; $\mathrm{Cys}(\mathrm{ACM})$ acetamidomethylcysteine; $\mathrm{DMF}=\mathrm{N}, \mathrm{N}$-dimethylformamide; $\mathrm{EDTA}=$ ethylene diamine tetraacetic acid; $\mathrm{FA}=$ furylacryloyl $; \mathrm{Gu}-\mathrm{HCl}=$ guanidine hydrochloride; $\mathrm{HPLC}$ = high performance liquid chromatography; Mes $=2$-( $\mathrm{N}$-morpholino)ethane sulfonic acid; $\mathrm{Ph}-\mathrm{Hg}^{+}=$phenylmercuric ions; Ph-Hg-CPD-Y = CPD-Y modified with phenylmercuric chloride; SDS = sodium dodecyl sulfate; TEA $=$ triethylamine; TFA $=$ trifluoroacetic acid. Abbreviations of amino acids are according to the guidelines of the IUPAC-IUB Commission on Biochemical Nomenclature. The binding site notation is that of SCHECHTER and BERGER (15). Accordingly, the binding site of the C-terminal amino acid residue of the substrate is denoted $\mathrm{S}_{1}^{\prime}$ and those of the amino acid residues in the $\mathrm{N}$-terminal direction away from the scissile bond are denoted $\mathrm{S}_{1}, \mathrm{~S}_{2}, \ldots . ., \mathrm{S}_{1}$. Amino acid residues in the substrate are referred to as $\mathbf{P}_{1}, \mathbf{P}_{2}, \ldots ., \mathbf{P}_{\mathrm{i}}$ in correspondence with the substrate. 
This enzyme releases all amino acids from the C-terminus of peptides; it exhibits a preference for peptides containing hydrophobic amino acid residues (except proline) but hydrophilic and charged amino acids are also released, albeit with very low rates $(6,9,10)$. Although this wide specificity of CPD-Y permits the digestion of most peptides and proteins with accessible $C$ termini, the sequence analysis is complicated whenever a slowly cleaved peptide bond is succeeded by one or several faster cleaved bonds such that it appears that several amino acids are released as a block. In such situations the application of serine carboxypeptidases with significantly different substrate preferences might be advantageous. Malted barley contains five serine carboxypeptidases with different specificities (14), two of which have been isolated and characterized in this laboratory $(4,7)$. Carboxypeptidase I from malt has a specificity related to that of CPD-Y $(4,5)$ and thus, it is of limited interest for sequence determinations. Carboxypeptidase II from malt (CPD-M-II), on the other hand, releases Arg and Lys with high rates, hydrophobic amino acids with intermediary rates and uncharged hydrophilic and acidic amino acids with low rates $(7,8)$. This specificity deviates from that of other serine carboxypeptidases and also from that of (metallo) carboxypeptidase B which only releases Arg and Lys (1). The present paper summarizes the experiences collected from digestions of a series of peptides with CPD-Y and CPD-M-II. It is shown that these two enzymes may supplement each other and that CPD-M-II is particularly suited for digestions of peptides with Arg or Lys at the ultimate position, e.g. tryptic peptides.

\section{MATERIALS AND METHODS}

\subsection{Materials}

CPD-M-II, Ph-Hg-CPD-Y and FA-Phe-LeuOH were prepared as previously described $(3,6$, 7). CPD-Y, Bz-Arg-Gly-Ala-Cys(ACM)-Lys$\mathrm{OH}$ and $\mathrm{H}-\mathrm{Gly}-\mathrm{Ser}-\mathrm{His}-\mathrm{Lys}-\mathrm{OH}$ were obtained from Carlsberg Biotechnology, Inc., Denmark. Bovine ribonuclease A, the B-chain of oxidized porcine insulin and Mes were obtained from Sigma, USA. Porcine glucagon was a gift from Novo Industries, Denmark, and FA-Ala-Lys-
$\mathrm{OH}$ and 2-vinylpyridine were purchased from Bachem, Switzerland and Janssen, Belgium, respectively. All other materials were of analytical grade and obtained from Merck, W. Germany.

\subsection{Methods}

The stabilities of CPD-Y and CPD-M-II were studied by incubating the enzymes (approximately $\left.0.1 \mathrm{mg} \cdot \mathrm{ml}^{-1}\right)$ at $25{ }^{\circ} \mathrm{C}$ in buffers $(0.05$ M-Mes, 1 mM-EDTA, pH 6.5 or 0.05 M-sodium acetate, $1 \mathrm{mM}$-EDTA, pH 4.3) with denaturing agents included. At various times aliquots were taken and the peptidase activity determined, using either FA-Phe-Leu-OH (CPD-Y) or FAAla-Lys-OH (CPD-M-II) as substrates, respectively. The assay mixture consisted of $965 \mu \mathrm{l}$ buffer (see above) $25 \mu \mathrm{l} 8 \mathrm{~mm}$ substrate in methanol and $10 \mu \mathrm{l}$ enzyme solution, thus diluting the concentration of denaturing agents. The rate of hydrolysis was monitored spectrophotometrically at $337 \mathrm{~nm}$ using a Cary 219 spectrophotometer. The initial activities of the enzymes in the presence of the original concentrations of denaturing agents were also determined by including these agents in the assay mixture such that they were not diluted during the spectrophotometric assay.

Oxidized ribonuclease $\mathrm{A}$ was prepared by treatment with performic acid followed by lyophilization (12). Reduced and alkylated ribonuclease A was prepared in the following way: $200 \mathrm{mg}$ ribonuclease was dissolved in $10 \mathrm{ml} 0.2$ M-Tris-HCl, 7 M-Gu-HCl, 5 mm-EDTA, pH 7.6 and bubbled with nitrogen for 10 minutes, followed by addition of $70 \mathrm{mg}$ dithiothreitol. After 2 hours, three $70 \mu \mathrm{l}$ 2-vinylpyridine aliqouts were added over 20 minutes and after reaction for an additional 10 minutes $\mathrm{pH}$ was lowered to 4.0 by addition of glacial acetic acid. The reaction mixture was dialysed against $2 \%$ acetic acid, 5\% ethanol and then lyophilized.

Tryptic peptides of ribonuclease were prepared in the following way: $20 \mathrm{mg}$ reduced and alkylated ribonuclease (see above) was dissolved in $10 \mathrm{ml}$ water and $\mathrm{pH}$ was adjusted to 8.0 by addition of $\mathrm{NaOH}$. Trypsin $(0.42 \mathrm{mg})$, dissolved in $0.001 \mathrm{M}-\mathrm{HCl}$, was added and $\mathrm{pH}$ was kept constant by titration with $0.1 \mathrm{M}-\mathrm{NaOH}$ in a pH stat. After 5 hours the reaction was terminated 
by addition of $25 \mu 1$ TFA. The tryptic peptides were fractionated by HPLC using equipment from Waters Associates and $\mathrm{a}_{18} 5 \mu$ Novapak reverse phase column. The elution was accomplished with a linear gradient from $0.1 \%$ TFA to $0.1 \%$ TFA in $45 \% \mathrm{CH}_{3} \mathrm{CN}$. The collected fractions were lyophilized and the amino acid compositions determined using a Waters Pico Tag System. Fractions containing more than a single peptide were rechromatographed on a Vydac reverse phase column using buffer system, gradient and equipment as described above.

C-terminal sequence determinations with CPD-Y and CPD-M-II were performed at $\mathrm{pH}$ values ranging from 4 to 7 in the presence of 1 mM-EDTA, using $0.05 \mathrm{M}$-sodium acetate or Mes as buffers. In cases where the peptide was insoluble at the required $\mathrm{pH}$, solubilisation was attempted at low $\mathrm{pH}$ in dilute acetic acid followed by dilution and adjustment of $\mathrm{pH}$ with $\mathrm{NaOH}$. With intervals aliquots of the reaction mixture were acidified ( $\mathrm{pH} 2$ ) by addition of sufficient TFA or $\mathrm{HCl}$, hence terminating the reaction.

The digestion mixture was analysed in two ways. In the direct method as described by AMBLER (1) the amount of each amino acid released was determined in the aliquots using either a Durrum D-500 amino acid analyser (3-8 nmoles) or the Waters Pico Tag System (0.1 - 1 nmoles). The relative rates of release of these amino acids reflect the C-terminal sequence. Alternatively, in the indirect method (17), the complete series of peptide intermediates were isolated from the aliquots and identified by amino acid analysis, thus permitting the establishment of the sequence of the original peptide. This method was used in the case of the ribonuclease peptides $\mathrm{Lys}^{1}-\mathrm{Arg}^{10}$ and $\mathrm{Glu}^{86}$-Lys ${ }^{98}$ : the residual peptides were separated by a Pharmacia FPLC system equipped with a PEP-RPC column, eluted with a linear gradient from $0.1 \%$ TFA to $0.1 \%$ TFA in $27 \% \mathrm{CH}_{3} \mathrm{CN}$.

A search for sequences resistant to carboxypeptidase digestion was performed by treatment of the mixture of tryptic peptides from reduced ribonuclease with CPD-M-II in the following way: $2.5 \mathrm{ml}$ solution of tryptic peptides (see above) was adjusted to $\mathrm{pH} 4.3$ by addition of $\mathrm{NaOH}$ and $100 \mu \mathrm{l}$ CPD-M-II (6 $\mathrm{mg} / \mathrm{ml}$ ) was added. During the reaction, which was carried out at $30^{\circ} \mathrm{C}, 60 \mu \mathrm{l}$ aliquots were withdrawn and, after termination of the reaction by addition of $1 \mu \mathrm{l}$ TFA, analyzed by HPLC, using a Novapak $\mathrm{C}_{18}$ column as described above. The reaction was terminated after 22 hours and the peptides in the fractions collected from the HPLC were identified by amino acid analysis.

Table I. Stability of carboxypeptidase $Y$ and malt carboxypeptidase II in solubilizing media

\begin{tabular}{|c|c|c|c|c|c|c|c|}
\hline \multirow{3}{*}{ Agent added } & \multicolumn{4}{|c|}{ Half-lives (min) } & \multicolumn{3}{|c|}{$\%$ activity in medium } \\
\hline & \multicolumn{2}{|c|}{$\mathrm{pH} 4.3$} & \multicolumn{2}{|c|}{$\mathrm{pH} 6.5$} & \multirow{2}{*}{$\frac{\mathrm{pH} 4.3}{\text { CPD-M-II }}$} & \multicolumn{2}{|c|}{$\mathrm{pH} 6.5$} \\
\hline & CPD-Y & CPD-M-II & CPD-Y & CPD-M-II & & CPD-Y & CPD-M-II \\
\hline 3 M-urea & 180 & stable & stable & stable & 45 & 100 & 45 \\
\hline $6 \mathrm{M}$-urea & 8 & 30 & 120 & $>240$ & 15 & 60 & 15 \\
\hline 3 м-Gu-HCl & 3 & 130 & 4 & 150 & 0 & & 0 \\
\hline $6 \mathrm{M}-\mathrm{Gu}-\mathrm{HCl}$ & $<1$ & $<1$ & $<1$ & $<1$ & & & \\
\hline $0.1 \%$ SDS & $<1$ & $<1$ & 180 & 60 & & 75 & 90 \\
\hline $0.5 \%$ SDS & $<1$ & $<1$ & 100 & $<1$ & & 75 & \\
\hline $10 \%$ Brij-35 & stable & stable & stable & stable & 95 & 40 & 80 \\
\hline $10 \%$ Triton $X-100$ & stable & stable & stable & stable & 100 & 40 & 95 \\
\hline $20 \%$ DMF & 40 & stable & 65 & stable & 25 & 25 & \\
\hline
\end{tabular}

The half-lives were determined after a 1:100 dilution of the enzyme-containing medium into the assay mixture, i.e. the solubilizing agent is diluted 1:100. The activity in the medium was determined by assay of activity in the same medium, i.e. no dilution of the solubilizing agent takes place (see section 2.2.). Stable : no activity loss measured within four hours. 


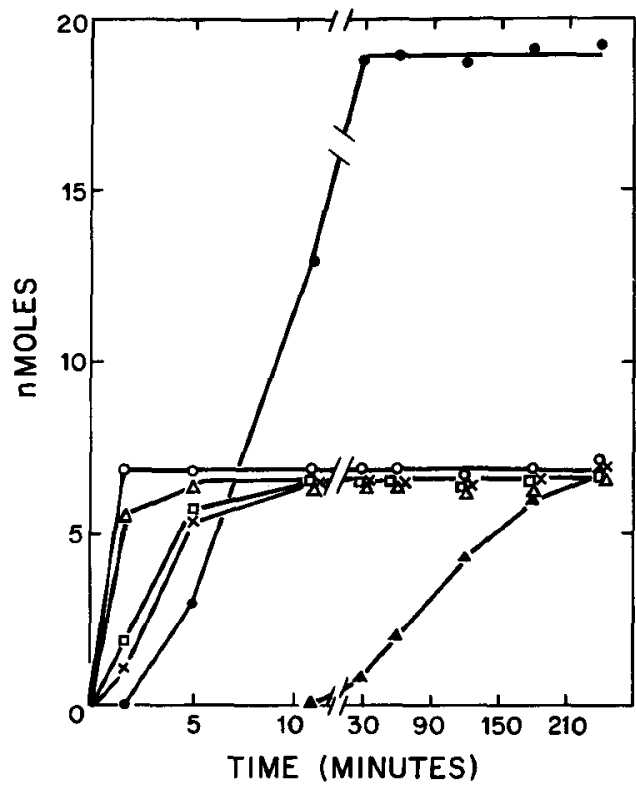

Figure 1. Analysis of liberation of amino acids during digestion of the ribonuclease fragment Lys'-Arg ${ }^{10}$ with carboxypeptidase II. Reaction conditions, see Table 1I, No 3. At the times indicated $30 \mu$ aliquots were withdrawn, acidified by addition of $5 \mu l 0.5$ $\mathrm{M}-\mathrm{HCl}$, and $20 \mu \mathrm{l}$ was applied directly to the Durrum amino acid analyzer. The ordinate indicates nmoles of the released amino acids: Arg $O$, Glu $\Delta$, Phe $\square$, Lys $\times$, Ala 9 , Thr $\mathbf{A}$

\section{RESULTS AND DISCUSSION}

The CPD-M-II and CPD-Y catalyzed release of amino acids with uncharged side-chains from peptides have maximal $\mathrm{k}_{\mathrm{ca}} / \mathrm{K}_{\mathrm{m}}$ at $\mathrm{pH} 4.3$ and $\mathrm{pH}$ 5.5 , respectively $(6,8)$. However, both enzymes exhibit sufficient activity and stability to permit digestions of peptides in the $\mathrm{pH}$ range $3.5-7$. This tolerance is convenient when the peptide is soluble only within a $\mathrm{pH}$ range which differs from the $\mathrm{pH}$ optimum of the enzyme. In some cases, where the peptide or protein was insoluble within the $\mathrm{pH}$ range where the enzyme is active, solubilisation was possible at low $\mathrm{pH}$ in dilute acetic acid, followed by adjustment of $\mathrm{pH}$ with $\mathrm{NaOH}$. This procedure allowed solubilization of the otherwise insoluble porcine glucagon at a concentration of $0.3 \mathrm{~mm}$ at $\mathrm{pH} 4.3$. However, in other cases low solubility has required addition of solubilizing agents, e.g. urea, SDS etc., and
Table I lists the stabilities of CPD-M-II and CPD-Y at pH 4.3 and 6.5 in the presence of such agents. The values listed are approximate halflives, based on only five activity measurements which do not allow the reaction order to be established. The initial activities of the two enzymes in these media are also listed as per cent of the control. For use in C-terminal digestions in the presence of solubilizing agents the enzyme should preferentially exhibit more than $10 \%$ initial activity, and a half-life above 10 minutes such that the time course of amino acid release can be studied. From Table I it is seen that $10 \%$ Brij-35, 10\% Triton X-100, 3 M-urea and 20\% DMF are permissible media with both enzymes at $\mathrm{pH} 4.3$ and 6.5. $6 \mathrm{M}$-urea is permissible with malt carboxypeptidase II at both $\mathrm{pH} 4.3$ and 6.5 but for CPD-Y only at $\mathrm{pH} 6.5$. Gu-HCl is not permissible, and SDS only at $\mathrm{pH} 6.5$ where $0.1 \%$ is tolerated by both enzymes while $0.5 \%$ is tolerated only by CPD-Y. It is apparent that both enzymes are more stable at $\mathrm{pH} 6.5$ than at pH 4.3 and that CPD-M-II is more stable than CPD-Y in urea, $\mathrm{Gu}-\mathrm{HCl}$ and DMF, while the opposite relation holds in SDS.

As an example of a typical C-terminal sequence determination the digestion of the tryptic ribonuclease fragment $\mathrm{H}$-Lys ${ }^{1}-\mathrm{Glu}$-Thr-AlaAla-Ala-Lys-Phe-Glu-Arg-OH ${ }^{10}$ by CPD-M-II was followed by both the direct and indirect methods mentioned in section 2.2. The enzyme sequentially released eight amino acids with rates that allowed the assignment of their positions in the sequence (Figure 1 and Table II, No. 3) and with the exception of Lys $^{1}-$ Lys $^{7}$ and Lys $^{1}-\mathrm{Ala}^{4}$ the residual peptides, which appeared and disappeared during the digestion, could be isolated (Figure 2). It should be noted that the indirect method is time consuming and limited to the analysis of relatively short peptides, due to difficulties in separating long peptides differing only by a single amino acid residue. The direct method, on the other hand, is equally reliable with short and long peptides but it requires that the reaction medium is free from substances which interferes with the amino acid analysis, e.g. denaturing agents such as urea. Such agents are less likely to influence the analysis by the indirect method.

The rates of hydrolysis with CPD-Y and 
Table II. Digestion of peptides with malt carboxypeptidase II and carboxypeptidase Y

\begin{tabular}{|c|c|c|c|c|c|c|}
\hline $\begin{array}{l}\text { Pep- } \\
\text { tide } \\
\text { No. }\end{array}$ & enzyme & $\begin{array}{l}{[\mathrm{E}]} \\
\mu \mathrm{M}\end{array}$ & $\begin{array}{l}{[\mathrm{S}]} \\
\mu \mathrm{M}\end{array}$ & pH & $\begin{array}{l}\text { Length } \\
\text { of exp. } \\
\text { (min) }\end{array}$ & Sequence \\
\hline 1 & CPD-M $\mathbf{M}_{11}$ & 0.35 & 1400 & 4.3 & 240 & $\mathrm{FV} \mathrm{N} \ldots \ldots \mathrm{C}\left(\mathrm{SO}_{3}\right)$ G E R G FEY T P $\mathrm{K}$ \\
\hline 2 & CPD-Y & 6.3 & 1400 & 4.3 & 180 & F V N . . . C $\left(\mathrm{SO}_{3}^{-}\right)$GER G FF Yे T PKA \\
\hline 3 & CPD-M $\mathbf{M}_{11}$ & 0.25 & 250 & 4.3 & 240 & 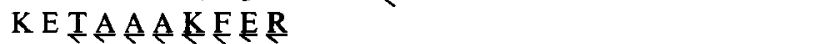 \\
\hline 4 & CPD-Y & 3.0 & 250 & 4.3 & 240 & KETAAAKFEB \\
\hline 5 & CPD-M $\mathbf{M}_{1 !}$ & 0.25 & 340 & 4.3 & 25 & E T G S S K Y P $\underset{\leftarrow}{\mathbf{N}} \underset{\mathrm{C}}{\mathrm{PE}} \underset{\mathrm{A}}{\mathrm{A}} \underset{\sim}{\mathrm{Y}} \underset{\underline{K}}{ }$ \\
\hline 6 & CPD-M $M_{11}$ & 0.31 & 200 & 4.1 & 25 & QH M D S T S A A S S S Y C(PE) NQ M M K \\
\hline 7 & CPD-M $M_{11}$ & 3.1 & 200 & 4.1 & 1200 & QH M D S T S A A S S S Y C PE N N MM K \\
\hline 8 & CPD-M $\mathbf{M}_{11}$ & 0.30 & 210 & 4.3 & 90 & K E T A A A $\underset{\perp}{K}$ \\
\hline 9 & CPD-M ${ }_{\mathrm{II}}$ & 0.77 & 210 & 4.3 & 30 & TTQA \\
\hline 10 & CPD-M $\mathrm{M}_{\mathrm{II}}$ & 0.77 & 210 & 4.3 & 100 & NLI K \\
\hline 11 & CPD-M $\mathbf{M}_{11}$ & 1.4 & 320 & 4.3 & 140 & V I L .......N E C(PE) G $S \perp A C(P E L F L H S K$ \\
\hline 12 & CPD-M $\mathbf{M}_{11}$ & 1.6 & 410 & 4.0 & 120 & 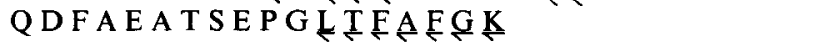 \\
\hline 13 & CPD-M & 0.70 & 500 & 4.3 & 6 & G S $\mathbf{H} \underline{\mathbf{K}}$ \\
\hline 14 & CPD-M $\mathbf{M}_{11}$ & 0.70 & 500 & 4.3 & 40 & $\mathrm{Bz}-\mathrm{R} \underline{\mathrm{GA}} \underline{\mathrm{C}}(\mathrm{ACM}) \underline{\mathrm{K}}$ \\
\hline 15 & $\mathrm{CPD}-\mathrm{M}_{11}$ & 0.53 & 360 & 4.3 & 240 & 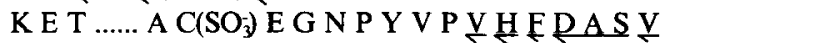 \\
\hline 16 & CPD-Y & 0.97 & 360 & 4.3 & 240 & K E T ...... A C $\left(\mathrm{SO}_{3}\right)$ E GNPYVPV \\
\hline \multirow[t]{2}{*}{17} & $\mathrm{Ph}-\mathrm{Hg}-$ & & & & & \\
\hline & CPD-Y & 2.2 & 500 & 5.0 & 80 & K E T ....... A C $\left(\mathrm{SO}_{3}^{-}\right)$E G N P Y V P V H F \\
\hline 18 & CPD-Y & 0.27 & 500 & 7.0 & 60 & KET ...... A C $\left(\mathrm{SO}_{3}\right)$ E G N P Y VPVHFDA \\
\hline 19 & $\begin{array}{l}{ }^{1)} \mathrm{CPD}-\mathrm{M} \\
{ }^{21} \mathrm{CPD}-\mathrm{Y}\end{array}$ & $\begin{array}{l}1.4 \\
2.0\end{array}$ & 360 & 4.3 & $\begin{array}{l}185 \\
240\end{array}$ & $\mathrm{~K} \mathrm{E} \mathrm{T} \mathrm{.......} \mathrm{A} \mathrm{C}\left(\mathrm{SO}_{3}\right)$ E G N P Y Y \\
\hline 20 & CPD-M & 2.2 & 285 & 4.0 & 180 & HSQGTFTSPYSKYLDSRRAQDFVQWLMNT \\
\hline 21 & CPD-Y & 1.9 & 285 & 4.0 & 180 & HS QGTFTSDYSKYLDSRRAQDEVQWLN \\
\hline 22 & CPD-M $M_{I I}$ & 0.2 & 170 & 4.0 & 120 & GQV \\
\hline 23 & CPD-M & 10 & 75 & $6.5^{\mathrm{a})}$ & 360 & A P Q \\
\hline
\end{tabular}

The experiments were performed with the following peptides: $1+2$ : B-chain of oxidized porcine insulin. $3+4$ : ribonuclease fragment $\mathrm{Lys}^{1}-\mathrm{Arg}^{10}$, 5: ribonuclease fragment $\mathrm{Glu}^{86}-\mathrm{Lys}^{98}, 6+7$ : ribonuclease fragment $\mathrm{Gln}^{11}-\mathrm{Lys}^{31}$, 8: ribonuclease fragment Lys ${ }^{1}-$ Lys $^{7}$, 9: ribonuclease fragment $\operatorname{Thr}^{99}-\mathrm{Lys}^{104}, 10$ : ribonuclease $\mathrm{Ass}^{34}-\mathrm{Lys}^{37}, 11$ : yeast protease A fragment $\mathrm{Val}^{30}{ }^{3} \mathrm{Lys}^{56}, 12$ : yeast protease A fragment $\mathrm{Gln}^{100}-\mathrm{Lys}^{117}, 15-19$ : oxidized ribonuclease, 20 + 21: porcine glucagon, 22: Gly ${ }^{102}-$ Leu $^{148}$ of the B-chain of malt carboxypeptidase I, 23: A-chain of malt carboxypeptidase I. a) contains $0.1 \%$ SDS.

Short arrows comprising only single amino acids indicate a time course which allows the position in the sequence of these amino acids to be identified. Long arrows comprising more than a single amino acid indicate that the position of these in the sequence cannot be distinguished. A punctuation indicates that part of the sequence has been omitted.

CPD-M-II are strongly affected by the nature of the amino acid residues occupying the ultimate and penultimate positions of peptide substrates $(4,5,6,7,10)$ and consequently, the individual steps in the sequential releases of amino acids from peptides are characterised by widely different rates. In cases where a slowly released amino acid is followed by one or more faster released amino acids it is not possible to decide the order of these amino acids in the sequence.
Examples of this are the digestions with CPD-Y of the ribonuclease fragment $\mathrm{Lys}^{1}-\mathrm{Arg}^{10}$ (Figure 3 and Table II, No. 4) and the B-chain of oxidized porcine insulin with the $\mathrm{C}$-terminal sequence -Arg-Gly-Phe-Phe-Tyr-Thr-Pro-LysAla-OH (Table II, No. 2). In the former case arginine and glutamic acid are rapidly released with sufficiently different rates to assign their positions in the sequence but the following five amino acids are released in a block. In the latter 


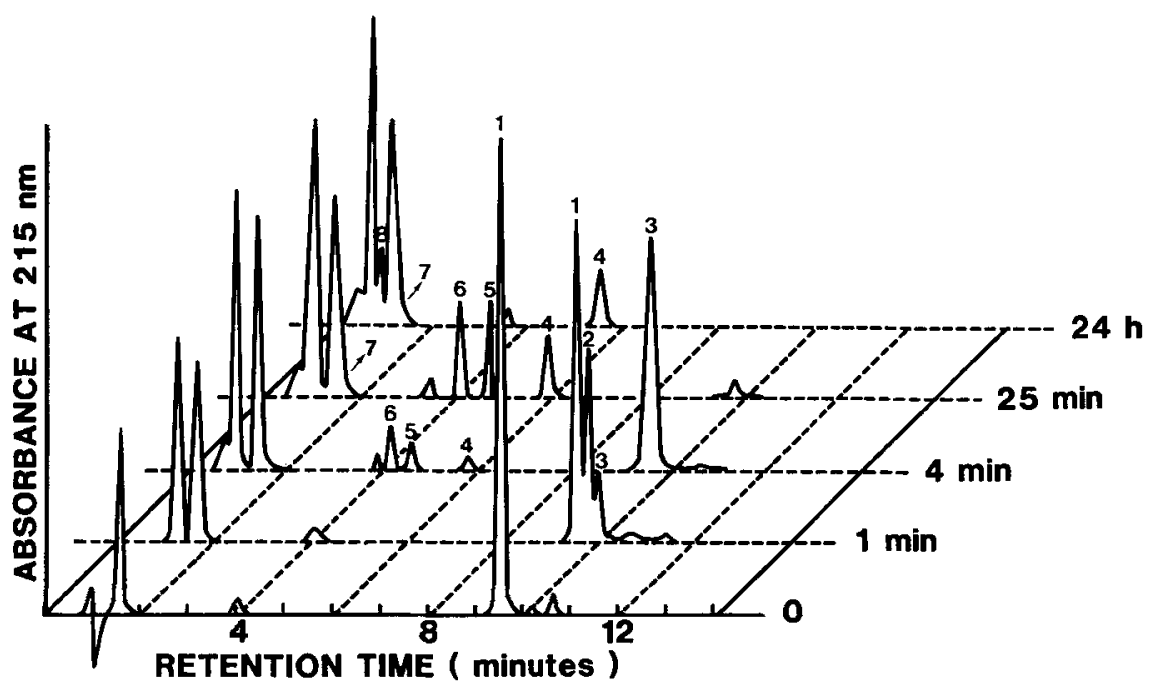

Figure 2. FPLC chromatograms obtained from digestion of the ribonuclease fragment Lys ${ }^{1}-\mathrm{Arg}^{10}$ with CPD-M-II. Reaction conditions, see Table II, No 3. At the times indicated $30 \mu \mathrm{l}$ aliquots were withdrawn, acidified by the addition of $5 \mu 10 \%$ TFA, and subjected to FPLC chromatography (see section 2.2). The figure shows the chromatogram as a function of time. The assignments of the peaks were based on amino acid compositions: 1 :

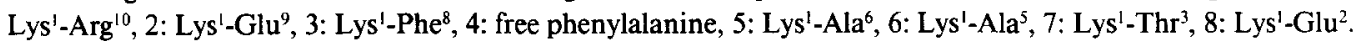

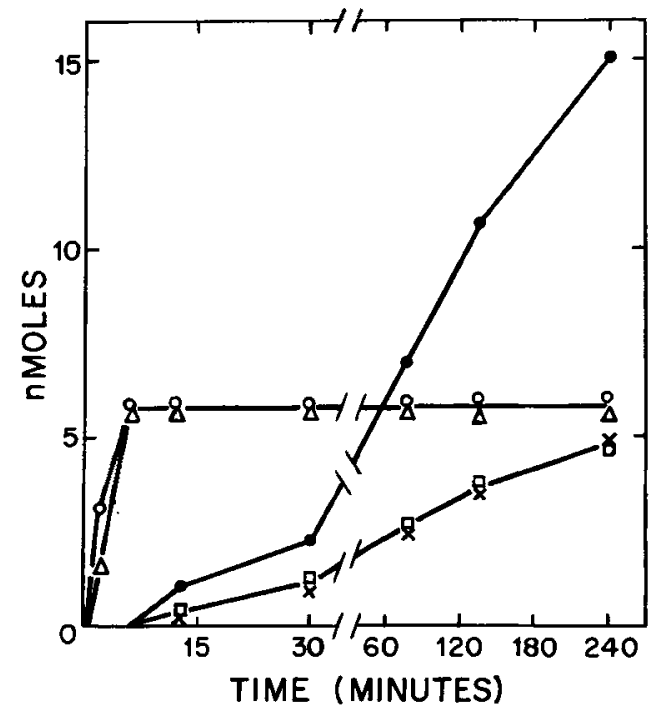

Figure 3. Digestion of the ribonuclease fragment Lys 1 $\operatorname{Arg}^{10}$ with CPD-Y. Reaction conditions, see Table II, No 4 . At the times indicated $30 \mu \mathrm{l}$ of the reaction mixture was withdrawn, acidified by the addition of 5 $\mu l 0.5 \mathrm{M}-\mathrm{HCl}$, and $20 \mu \mathrm{l}$ was added directly to the amino acid analyzer. The symbols represent the amino acids shown in Figure 1. case the C-terminal acid plus the following six amino acids are released in a block. This is due to the preference of CPD-Y for substrates with alanine, methionine, leucine, phenylalanine, tyrosine and tryptophan in the penultimate position and for the same amino acids plus valine and isoleucine in the ultimate position. Peptides with lysine and arginine in the penultimate position are hydrolysed with extremely low rates and thus, the Lys-Phe bond in the decapeptide and the Lys-Ala bond in the B-chain are cleaved very slowly compared with the following peptide bonds. CPD-M-II, on the other hand, exhibits a preference for those with phenylalanine, lysine, arginine, leucine, methionine, histidine and alanine in the penultimate position and primarily lysine and arginine but to some extent also isoleucine, methionine, phenylalanine and valine in the ultimate position. Thus, while CPD-Y exhibits a preference exclusively for hydrophobic amino acid residues CPD-M-II exhibits one for hydrophobic plus basic amino acid residues, and when this enzyme was used for the digestion of the same two peptides the rapid cleavages of 


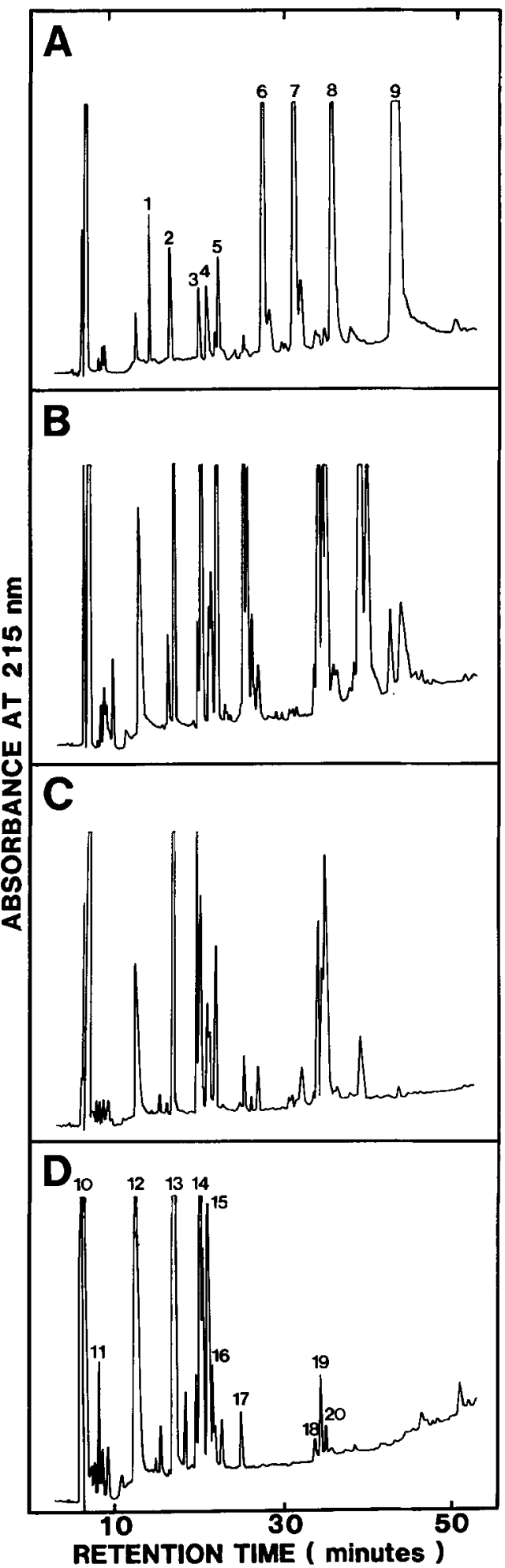

Figure 4. Digestion of the mixture of tryptic peptides from ribonuclease with CPD-M-II. Reaction conditions, see section 2.2. Panel A. HPLC chromatography of $50 \mu \mathrm{l}$ aliquot before addition of carboxypeptidase $(t=0)$. The numbers indicate the assignments of each peak, based on amino acid analysis. Panel B: after 9 min reaction. Panel C: after 2 hours reaction. Panel D: after 22 hours reaction. The assignments indicated are based on amino acid analysis: 1: Thr $^{99}-$ Lys $^{104}, 2$ : Lys $^{1}-$ Lys $^{7}, 3:$ Asn $^{62}-$ Lys $^{66}$, 4: Asn $^{34}-$ Lys $^{37}$, 5: Phe ${ }^{8}-$ Arg $^{10}$, 6: Lys' $^{1}-$ Arg $^{10}+$ Glu $^{86}-$ Lys $^{98}$, 7: Gln $^{11}-$ Lys $^{31}$, 8: Asn $^{68}$ $\mathrm{Arg}^{85}, 9: \mathrm{His}^{105}-\mathrm{Val}^{124}, 10$ : free amino acids apart from tyrosine and phenylalanine, 11: Glu' ${ }^{11}-\mathrm{His}^{12}$, 12: free tyrosine, 13: free phenylanaline + $\mathrm{Gln}^{11}-\mathrm{Ser}^{18}+\mathrm{His}^{105}$ $\mathrm{Ile}^{106}+\mathrm{Asn}^{34}-\mathrm{Leu}^{35}, 14: \mathrm{Tyr}^{92}-\mathrm{Asn}^{94}+\mathrm{Gln}^{11}-\mathrm{Tyr}^{25}, 15$ : $\mathrm{Gln}^{11}-\mathrm{Ala}^{19}+\mathrm{Gln}^{11}-\mathrm{Ser}^{23}, 16: \mathrm{Gln}^{11}-\mathrm{Asn}^{94}, 17: \mathrm{Tyr}^{92}-$ Pro $^{93}$, 18: Asn $^{67}-$ Thr $^{83}$, 19: Asn $^{67}-$ Ile $^{81}$, 20: Asn $^{67}$-Arg ${ }^{85}$.

the Glu-Arg, Lys-Phe and Ala-Lys bonds in the ribonuclease fragment $\mathrm{Lys}^{1}-\mathrm{Arg}^{10}$ (Figure 1 and Table II No. 3) and the Lys-Ala and Pro-Lys bonds in the B-chain (Table II, No. 1) rendered the results much more informative.

The C-terminal sequence of peptides which contain Lys or Arg in their C-terminal positions is best determined with CPD-M-II since this secures a fast release of the first amino acid. A number of tryptic peptides from ribonuclease, purified by HPLC (Figure 4A), were digested with CPD-M-II as seen from Table II, No. 3 and 5 to 12 . In all cases the identity of two or more of the C-terminal amino acid residues could be established.

The presence of several hydrophobic amino acid residues and the absence of Arg and Lys in the C-terminal portion of porcine glucagon renders digestion of this peptide with CPD-Y advantageous over digestion with CPD-M-II (Table II No. 20 and 21). Good sequence data are frequently obtained when the digestion slows down approximately 10 amino acid residues away from the C-terminus as seen with the very slow hydrolysis by CPD-Y of the Arg-Arg bond in example No. 21. Similarly, a prolyl residue is sometimes a stopping block for CPD-M-II as seen with the Val-Pro bond in oxidized ribonuclease (Table II, No 15).

To investigate the possible function of specific amino acid sequences as stopping blocks the 
complete mixture of the tryptic peptides from reduced and ethylpyridylated ribonuclease was subjected to extensive digestion with CPD-M-II. During the reaction aliquots were withdrawn and fractionated by HPLC chromatography (Figure 4). Most of the peptides present before addition of CPD-M-II (Figure 4A) disappeared within the first 9 minutes (Figure 4B). After 2 hours only small amounts of peptides eluting later than 30 minutes were left (Figure $4 \mathrm{C}$ ) and after 22 hours they had practically disappeared (Figure 4D). The fractions obtained by HPLC of this final aliquot were subjected to amino acid analysis and when a fraction contained more than a single peptide further HPLC purification was performed, resulting in the assignments listed in Figure 4D. Large peaks contain, in addition to free amino acids, the di- and tripeptides $\mathrm{GIn}^{11}-\mathrm{His}^{12}, \mathrm{Asn}^{34}-\mathrm{Leu}^{35}$, $\mathrm{His}^{105}-\mathrm{Ile}^{106}$, and $\mathrm{Tyr}^{92}-\mathrm{Pro}^{94}$. Only small amounts ( $2 \%$ of the original peptide) of $\mathrm{Asn}^{67}$ - $\mathrm{Arg}^{85}$ and its degradation products $\left(\mathrm{Asn}^{67}-\mathrm{Asp}^{83}\right.$ and $\mathrm{Asn}^{67}-\mathrm{Ile}^{81}$ ) were found. The only longer peptide present in significant amounts is Gln ${ }^{11}$-His-Met-Asp-Ser-SerThr-Ser-Ala-Ala-Ser-Ser-Ser ${ }^{23}$ (35\%) and its further degradation products Gln ${ }^{11}$-Ala ${ }^{19}$ (approx. $5 \%$ ) and $\mathrm{Gln}^{11}-\mathrm{Ser}^{18}$ (approx. 5\%). This indicates that dipeptides and polypeptides with an unbroken sequence of hydroxy amino acids are extremely poor substrates of CPD-M-II.

In some cases stopping blocks may be introduced into peptide chains by chemical modifications of particular amino acid residues. Oxidation of a peptide with performic acid converts cysteine and cystine to cysteic acid and methionine to methionine sulfone, and neither of these are released by either the two carboxypeptidases as shown for cysteic acid in Table II, No. 16 and 19. On the other hand, in cases where such a stopping block is not desirable necessary conversion of cystine should be performed by reduction and alkylation.

The slow-down of particular steps may also be achieved by chemical modification of the enzyme used for the digestion. In the CPD-Y catalyzed digestion of oxidized ribonuclease at pH 4.3 (Table II, No. 16) alanine and aspartic acid are released with identical rates through cleavage of the Asp-Ala and Phe-Asp bonds, respectively, such that their positions cannot be distinguished. This is due to the high preference of CPD-Y for hydrophobic amino acid residues like phenylalanine in the penultimate position such that the Phe-Asp bond is rapidly hydrolysed. This preference is drastically reduced by modification of $\mathrm{Cys}^{341}$, located in the $\mathrm{S}_{1}$ binding site of CPD-Y, with $\mathrm{Ph}-\mathrm{Hg}^{+}$(3), and when this modified enzyme is used for the digestion of oxidized ribonuclease the rate of cleavage of the Phe-Asp bond is reduced sufficiently to distinguish the release of alanine from the release of aspartic acid (Table II, No. 17).

The fact that CPD-Y and CPD-M-II in digestions of peptides are slowed down by different amino acid residues can be exploited in determination of C-terminal sequences. When CPD-M$\mathrm{II}$ acts on oxidized ribonuclease it releases seven amino acids from the C-terminus with -Asp-AlaSer- in a block and less than $5 \%$ of the following proline residue is released (Table II, No. 15). Addition of CPD-Y at this point of the reaction releases another six amino acids, and provides more sequence information than that obtained from digestion with carboxypeptidase II alone (Table II, No. 19) or with CPD-Y alone (Table II, No. 16).

Ambiguities experienced when the digestion of peptides is followed by analysis of the released amino acids can often be resolved by altering the conditions of digestion such that the rate(s) of the slow step(s) is increased or the rate(s) of the subsequent fast step(s) is decreased. An example is the action of CPD-Y on oxidized ribonuclease at pH 4.3 and 7.0 (Table II, No. 16 and 18). At both pH 4.3 and 7 the release of first valine and then serine can be distinguished. However, at $\mathrm{pH}$ 7 the following seven amino acids are released as a block whereas at $\mathrm{pH} 4.3$ alanine and aspartic acid are released together, followed by phenylalanine and finally a block of four amino acids. This difference is due to CPD-Y hydrolysing N-blocked di-peptide substrates containing aspartic acid or glutamic acid in the ultimate and/or the penultimate positions at lower rates at $\mathrm{pH}$ values above $\mathrm{pH} 5.5$ where their sidechains are largely in the negatively charged carboxylate form as compared with those at lower $\mathrm{pH}$ values where they are in the uncharged carboxylic acid form (10). Thus, at $\mathrm{pH} 7$ the release of alanine from ribonuclease is slow and 
rate-limiting due to the penultimate aspartic acid being negatively charged. This influence of pH allows some control over the relative rates with which the enzyme "passes" through acidic amino acid residues in peptides thus providing a mean to obtain a more interpretable time course for the release of amino acids from the peptide.

In summary, utilization of the carboxypeptidase catalyzed consecutive release of amino acids from the $\mathrm{C}$-terminus of peptides for the determination of amino acid sequences requires that the release of each amino acid can be distinguished. When this is not possible it is somtimes advantageous to change the relative rates of the individual reactions by altering the conditions of digestion, e.g. $\mathrm{pH}$, or by using an additional carboxypeptidase with a different specifity. CPD-Y with its pronounced preference for peptides with hydrophobic amino acid residues at both the $P_{1}$ and $P_{1}^{\prime}$ positions, and CPD-M-II with its preference for the basic amino acid residues supplement each other. However, they both only slowly release threonine, serine, asparagine, glutamine, glutamic acid, aspartic acid and proline, and before carboxypeptidases with preferences for these amino acids become available $\mathrm{C}$-terminal sequence determinations will in many cases remain problematic.

\section{ACKNOWLEDGEMENTS}

The excellent technical assistance of Mss. Hanne Christiansen and Pia BredDam is acknowledged. Dr. THOMAS DREYER is thanked for the tryptic peptides from protease A.

\section{REFERENCES}

1. Ambler. R.P.: Carboxypeptidases A and B. Eds. C. H. W. Hirs \& S. N. Timasheff, Academic Press. Methods Enzymol. 25, 262-272 (1972)

2. Breddam, K., F. Widmer \& J. T. Johansen: Carboxypeptidase $\mathrm{Y}$ catalyzed transpeptidations and enzymatic peptide synthesis. Carlsberg Res. Commun. 45, 237-247 (1980)
3. Breddam, K.: Modification of the single sulfhydryl group of carboxypeptidase Y. Carisberg Res. Commun. 48, 9-19 (1983)

4. BREdDam, K., S. B. Sørensen \& M. Ottesen: Isolation of a carboxypeptidase from malted barley by affinity chromatography. Carlsberg Res. Commun. 48, 217-230 (1983)

5. BREDDAM, K. \& M. OTTESEN: Influence of guanidine derivatives on the specificity of malt carboxypeptidase. Carlsberg Res. Commun, 49, 573-582 (1983)

6. BREDDAM, K.: Chemically modified carboxypeptidase $\mathrm{Y}$ with increased amidase activity. Carlsberg Res. Commun. 49, 535-554 (1984)

7. BREddaM, K., S. B. Sørensen \& M. OtTesen: Isolation of carboxypeptidase II from malted barley by affinity chromatography. Carlsberg Res. Commun. 50, 199-209 (1985)

8. BREDDAM, K: Enzymatic properties of malt carboxypeptidase II in hydrolysis and aminolysis reactions. Carlsberg Res. Commun. 50, 309-323 (1985)

9. Breddam, K: Serine carboxypeptidases. A Review. Carlsberg Res. Commun. 51, 83-128 (1986)

10. Hayashi, R. Y. BaI \& T. Hata: Kinetic studies of carboxypeptidase Y. I. Kinetic parameters for the hydrolysis of synthetic substrates. J. Biochem. (Tokyo) 77, 69-79 (1975)

11. Hayashi. R.: Carboxypeptidase $\mathrm{Y}$ in sequence determination of peptides. Eds. C. H. W. Hirs \& S. N. Timasheff, Academic Press. Methods Enzymol. 47, 84-93 (1977)

12. HiRs. C. H. W.: Determination of cystine as cysteic acid. Meth. Enzymol. 45, 587-599 (1979)

13. Martin, B., I. SVEndSEn \& M. OtTesen: Use of carboxypeptidase $Y$ for carboxy terminal sequence determinations. Carlsberg Res. Commun. 42, 99 102 (1977)

14. Mikola. L. \& J. Mikola: Mobilization of proline in the starchy endosperm of germinating barley grain. Planta 149, 149-154 (1980)

15. SCHECHTER, I. \& B. BERGER: On the size of the active site of proteases. I. Papain. Biochem. Biophys. Res. Commun. 27. 157-162 (1967)

16. TsChesche, H.: Carboxypeptidase C. Eds. C. H. W. Hirs \& S. N. Timasheff, Academic Press. Methods Enzymol. 47, 73-84 (1977)

17. WAGNER, R. M.: Exopeptidase-high-performance liquid chromatography peptide mapping of small peptides. J. Chromatography. 326, 399-405 (1985) 